University of California, Hastings College of the Law UC Hastings Scholarship Repository

UC Hastings Faculty Books

2007

\title{
The Paradoxes of Nationalism: The French Revolution and its Meaning for Contemporary Nation building
}

Chimène Keitner

UC Hastings College of the Law

Follow this and additional works at: http://repository.uchastings.edu/faculty_books

\section{Recommended Citation}

Keitner, Chimène, "The Paradoxes of Nationalism: The French Revolution and its Meaning for Contemporary Nation building" (2007). UC Hastings Faculty Books. Book 10.

http://repository.uchastings.edu/faculty_books/10 
